\title{
HÉROES VAGABUNDOS: MEMORIA NARRATIVA DE LA GUERRA COLOMBIANA
}

Fecha de recepción: 31 de marzo de 2014 Fecha de aprobación: 7 de mayo de 2014

\section{Resumen}

La constante en Los ejércitos (2007) de Evelio Rosero (1958), Los derrotados (2012) de Pablo Montoya (1963) y El incendio de abril (2012) de Miguel Torres (194?) es la utilización de un personaje determinado por un principio nómada, que va de un lugar a otro sin origen, ni llegada, sin meta; artilugio narrativo para referir la violencia sociopolítica colombiana y su repercusión en la subjetividad individual y colectiva. El tratamiento narrativo está fundado en el devenir incesante, donde la voz que cuenta, siempre en primera persona, se distancia de la intención de explicar lo que ve y se aboca a la mera exploración de los efectos emocionales que el conflicto produce. En la experiencia cotidiana del terror se traduce la imposibilidad de la memoria, y la pérdida del territorio es detonante de la negación y el olvido.

Palabras clave: Miguel Torres, Evelio Rosero, Pablo Montoya, violencia sociopolítica, nomadismo, memoria histórica, espacios urbanos, héroe derrotado.

Artículo de reflexión del proyecto de investigación "Memoria narrativa del miedo político y la representación de sus efectos psicosociales en la literatura colombiana"

Citar: Vanegas Vásquez, O. (julio - diciembre de 2014). Héroes vagabundos: memoria narrativa de la guerra colombiana. La Palabra (25), 43-56
Orfa Kelita Vanegas Vásquez Universidad del Tolima, Colombia okvanegasv@ut.edu.co

Doctoranda en letras, Universidad de Cuyo, Mendoza - Argentina; Profesora asociada, Universidad del Tolima. 


\section{VAGABOND HEROES: NARRATIVE MEMORY OF THE COLOMBIAN WAR}

\section{Abstract}

The common issue in Los Ejércitos (2007) by Evelio Rosero (1958), Los Derrotados (2012) by Juan Pablo Montoya (1963) and El Incendio de Abril (2012) by Miguel Torres (194?) is the usage of a nomad character, this person goes from one place to another, comes from nowhere and goes towards nowhere; this is a mechanism to refer to the Colombian sociopolitical violence and its outcomes in the personal and collective subjectivity. The narrative plot is based on the never ending daily life, where the voice that tells, always in first person, is away from the intention of explaining what it is actually seen and this voice merely explores the emotional effects that the conflict produces. In the common terror experience the impossibility of the memory is displayed, and the loss of territory triggers the negation and the oblivion.

Key words: Miguel Torres, Evelio Rosero, Pablo Montoya, sociopolitical violence, nomadism, hostorical memory, urban spaces, defeated hero.

\section{HÉROS VAGABONDS: MÉMOIRE RÉCIT DE LA GUERRE COLOMBIENNE}

\section{Résumé}

Dans les livres Les armées (2007) de d'Evelio Rosero (1958), Los derrotados (2012) de Pablo Montoya (1963) et El incendio de abril (2012) de Miguel Torres (194?), la constante est l'utilisation d'un personnage déterminé par un principe nomade, quelqu'un qui va d'un lieu à un autre sans origine, sans arrivée, sans but. Il s'agit d'un subterfuge narratif pour faire référence à la violence sociopolitique colombienne et à sa répercussion sur la subjectivité individuelle et collective. Le texte narratif se fonde sur le devenir incessant, où la voix qui raconte, toujours à la première personne, s'éloigne de l'intention d'expliquer ce qu'elle voit, et abouti sur la pure et simple exploration des effets émotionnels produits par le conflit. Dans l'expérience quotidienne de la terreur il se révèle l'impossibilité de la mémoire, et la perte du territoire est le détonant de la négation et de l'oubli..

Mots clés: Miguel Torres, Evelio Rosero, Pablo Montoya, violence sociopolitique, nomadisme, mémoire historique, espaces urbains, héros abattu. 
Geografías de la memoria, el terror y el olvido

Escribir sobre la violencia sociopolítica no es nada nuevo en la literatura colombiana. La formación del país, que se ha dado en medio de enfrentamientos armados, asesinatos de líderes políticos, guerrillas enardecidas, narcotráfico y tensiones populares, "ha motivado" siempre a los escritores a interpretar los sucesos violentos, resituar la memoria histórica y establecer diferentes propuestas desde lo literario. Los hechos de la realidad política del país influyen poderosamente en el quehacer del escritor, quien se ve determinado a escribir casi exclusivamente sobre el tema de la violencia, y sino sobre su consecuencia inevitable: la humillación, la vergüenza, la derrota. "Las mejores obras de nuestra literatura, o al menos las más representativas, son el recuento de una hecatombe colectiva que sucede en las selvas, la saga sangrienta así haya resplandores mágicos de una familia de frustrados, el nihilismo de alguien que denuncia con irreverencia la sociedad criminal en que ha nacido" (Montoya, 2012, p. 145).

Las novelas elegidas para el presente estudio convergen nuevamente en la recreación de la violencia sociopolítica y sus efectos. Sin embargo, aunque el tema, una vez más, es la violencia, sorprende el recurso narrativo utilizado: un personaje que deambula por los lugares arrasados por las afrentas militares o civiles. La caracterización temática y formal surge del movimiento incierto, desasosegado, donde el nomadismo se presenta como la forma más efectiva para referir las atrocidades de la guerra, dando cuenta también de una literatura polimorfa, en el sentido que son narrativas que no se adhieren a un género específico y oscilan entre la novela, el registro histórico-periodístico, "el ensayo narrativo", el relato o la crónica testimonial. Propuestas estéticas que no encuentran límites y se desbordan del molde acostumbrado.

Desde una primera voz, ubicada del lado de los vencidos, se articula la trama y se entra de lleno a pasajes que registran el dolor y la valentía, la vergüenza y el miedo, la esperanza y la insensatez de la violencia. En Los ejércitos (2007) por ejemplo, es Ismael Pasos, un viejo profesor, que para encontrar a su mujer, desaparecida en medio de un atentado militar, emprende una búsqueda fatigosa por las calles destripadas de su pueblo; en $E l$ incendio de abril (2012) es Ana Barbusse, francesa radicada en Colombia, quien atraviesa la zona central de la capital durante El Bogotazo ${ }^{1}$; camina por sitios desolados, en medio de incendios y cruce de balas, buscando a su esposo Francisco; y en Los derrotados (2012) está Andrés Ramírez, un fotógrafo de guerra, que transita por poblaciones exterminadas mientras enfoca su cámara para engordar con su registro un "Catálogo de muertos" (Montoya, 2012, p. 112). Todos estos personajes son alegoría del asombro y el desgarramiento, que con su "testimonio ambulante" construyen o recuperan una "auténtica memoria" del país.

Las ficciones están ubicadas en lugares y momentos coyunturales de la historia colombiana: 9 de abril de 1948, los años setenta y ochenta, y la primera década del siglo XXI. Para dimensionar con mayor claridad la importancia en la delimitación del tiempo y el espacio escogido por los novelistas, es necesario enfatizar que Colombia padece de una guerra permanente, endémica, desde el periodo de la Independencia. Con un momento crítico y definitivo entre mediados de la década de los cua-

1 Suceso histórico desatado a raíz del asesinato del líder político Jorge Eliecer Gaitán el 9 de abril de 1948. Bogotá fue devastada por los enfrentamientos entre partidarios de varios grupos opuestos: liberales y conservadores, el Estado y los alzados en armas, los saqueadores y quienes trataban de recomponer el orden. 
renta y comienzos de la de los sesenta, cuando desemboca la Violencia, con mayúscula: brutal confrontación entre miembros de los partidos políticos liberal y conservador. Periodo multifacético y profundamente problemático, ya que fue no sólo un conflicto entre el movimiento popular y las clases dominantes, sino también entre las mismas clases dirigentes: especie de versión tardía de las guerras civiles decimonónicas (Sánchez, 2008, p. 13-24).

Los actos más nefastos de la Violencia se dieron a partir del asesinato del popular líder liberal Jorge Eliécer Gaitán en abril de 1948, hecho que para la mayoría de analistas partió la historia de Colombia en dos y generó uno de los periodos más sangrientos de la historia colombiana, donde perecieron cerca de doscientas mil personas y se impulsaron importantes cambios de orden sociopolítico (Sánchez, 2008, p. 28-63; Guzmán Campos, Fals Borda, Umaña Luna, 2010, p. 48-52). Un hito histórico que precisamente, Miguel Torres ha retomado en El incendio de abril ${ }^{2}$ con la clara intención de "desentrañar una verdad como sólo la ficción puede hacerlo: con la memoria transformada en imaginación" (Torres, 2013, p. 1), y desarticular de esa forma los ideologemas sociales, históricos y políticos sobre uno de los momentos más definitivos de la historia del país.

Rosero y Montoya ${ }^{3}$, en cambio, retoman los sucesos justamente después de la Violencia: sus secuelas. Configuran entonces, una serie de hechos desde la década de los setenta hasta nuestros días (primera década del siglo XXI); donde el conflicto sociopolítico se circunscribe al cruce de varias guerras: la de la guerrilla contra el Estado y contra los intereses paramilitares, y la del narcotráfico y su empoderamiento económico a través del terrorismo.

Siguiendo a Augusto Escobar (2000, p. 321-38), reconocido investigador de la literatura de la violencia en Colombia, no cabe duda que las letras nacionales siguen estableciendo fuertes vínculos con los diversos marcos de guerra que definen el acontecer del país. Es una narrativa aferrada a sucesos concretos, en un límite difuso entre realidad y ficción; surgida de las grietas, trozos o "restos de lo real" (Garramuño, 2009 , p. 54) y que busca conservarse como registro artístico fuertemente codificado para la preservación de una memoria histórica social. A propósito de Los ejércitos, y en relación a la violencia sociopolítica, Evelio Rosero aclara que su novela, aunque producto de la ficción y la virtualidad, es una radiografía de la guerra criminal colombiana, del dolor y el desamparo de las víctimas y la aniquilación de territorios enteros (Junieles, 2007, p. 1).

Ahora bien, se anunciaba líneas atrás que estas ficciones retienen como dispositivo narrativo estratégico al héroe nómada o vagabundo ${ }^{4}$; a través de una "errancia lúcida" (Avilés, 2012, p. 873) se señala el fuerte contenido de animalidad de la guerra, pero sobre todo se "reinventa" o modifica considerablemente el concepto de nomadismo. Un concepto que no es ya como tradicionalmente se había interpretado: el movimiento incesante para la "búsqueda de utopías", que alimentaba la "aspiración demiúrgica" del escritor como "creador de mundos" o "reinventor de los

2 El incendio de abril es la segunda parte de la trilogía el "Bogotazo", la cual comenzó con El crimen del siglo en el 2006.

3 Es necesario precisar que Pablo Montoya en Los derrotados configura diferentes planos temporales y espaciales. La novela cuenta la vida del Sabio Caldas en el siglo XIX; el devenir de tres amigos en su adolescencia durante las décadas de los setenta y los ochenta del siglo XX, y su adultez en la primera década del siglo XXI.

4 Las categorías de vagabundo, nómada y errante las dimensionamos desde Maffesoli (2005, p. 112-29) y Bauman (2001, p. 107-20) como conceptos críticos correlacionados. Son distintas modalidades de un mismo principio vector: el movimiento continuo del sujeto, ya sea porque necesita romper de manera voluntaria los límites establecidos y buscar nuevos horizontes o porque acosado por un contexto lacerante se ve obligado a caminar sin rumbo definido. 
espacios urbanos" (Giannini, 1987, p. 31; Maffesoli, 2005, p. 36; Aínsa, 2006, p. 145; Cassigoli, 2011, p. 92), sino el deambular sin sentido que registra un contexto de sensaciones, imágenes y contactos traumáticos del espacio que se habita; donde el personaje nómada es símbolo de la desorientación y la pérdida, es quien recoge los restos de la memoria social aferrada aún a los escombros de la ciudad caminada.

La figura del "caballero andante” (Maffesoli, 2005, p. 39) o del flâneur (Benjamin, 2005, p. 421) como héroes utópicos regidos por una condición nomádica ${ }^{5}$, deseosos del viaje, que miran la ciudad o el horizonte con ojos esperanzados, resulta marginal y anacrónica en el imaginario contemporáneo, y por ende para la configuración estética. El nomadismo no es ya ese "sueño tenaz que evoca el poder para instituir y por lo tanto alivia la pesadez mortífera de lo instituido" (Maffesoli, 2005, p. 40), su naturaleza se ha desvirtuado considerablemente. Aunque conserva todavía el principio del movimiento, de la búsqueda constante, su fin es otro, apunta ahora a un divagar en torno a sí mismo; a definir un sujeto sin horizonte utópico, reducido a su contexto inmediato, tratando de encon- trar en la realidad fracturada un algo que justifique su estar en el mundo.

Tradicionalmente la tendencia del desplazamiento del personaje por el espacio urbanizado se centró en el deseo de fundar una realidad diferente, traducida como sueño o utopía, donde los nuevos lugares simbolizaban la búsqueda de explicaciones o la simple evasión. Topos ficcionales producto de una tensión, de una escisión o de una disconformidad con lo real. Por ejemplo, Comala en la obra de Juan Rulfo o Macondo en el universo de Gabriel García Márquez siguen siendo por antonomasia los lugares míticos latinoamericanos que reflejan la aspiración demiúrgica del escritor, esa necesidad de invención de un espacio alternativo dónde situar la experiencia anímica del territorio que se habita. Ciertamente, se entiende que los escritores han cumplido un importante papel en la construcción de los imaginarios urbanos, atentos a los signos vitales de la urbe, exploran en su riqueza simbólica para configurarlos literariamente. Labor que ha llevado a que el conocimiento que tenemos de ciertas ciudades obedezca en gran medida, a la codificación encontrada en la literatura (Aínsa, 2006, p. 197; Avilés, 2012, p. 875).
Entonces, al comparar con los registros tradicionales los espacios urbanos que proponen Montoya, Rosero y Torres, la idea de evasión o de idealización que guardaban se desvirtúa totalmente. La conciencia topográfica de estos escritores no señala ya un sitio alterno, sino la aniquilación total de todo significado de la urbe, un no lugar. Los sitios comprometidos en la ficción son ahora los guiñapos o pedazos de poblaciones que ha dejado la guerra. La ciudad literaria ha mutado en "una geografía de la hecatombe" (Montoya, 2013, p. 1) donde se ancla el olvido y se hace imposible la proyección hacia el futuro.

La configuración literaria de la ciudad devastada, es una circunstancia que viene a determinar justamente la caracterización del personaje ubicado en esos espacios. Ahora es él un vagabundo sin remedio, que empujado desde atrás por una fuerza demasiado poderosa, esta lo obliga a un deambular angustioso, dejándolo sin raíces. La libertad, la autonomía, la independencia no son parte ya de la condición nomádica del héroe contemporáneo; él se ve lamentablemente obligado al movimiento incesante en un mundo inhóspito que se ha tragado su memoria, su identidad,

5 Sintagma utilizado por Fernando Aínsa (2012, p. 15) para señalar los sujetos o fenómenos sociales simbólicos del desarraigo, la migración o el éxodo. De aquello que en un desplazamiento constante da forma a una nueva cartografía de la pertenencia. 
su cultura (Bauman, 2001, p. 113).

Veamos algunos pasajes de las tres novelas elegidas que muestran lo anterior: de la vereda $\mathrm{El} \mathrm{Aro}{ }^{6}$, en Los derrotados (Montoya, 2012), se muestran imágenes de edificios y casas explotadas, que "algo tienen en su fachada que recuerda las tumbas de un pabellón de cementerio sórdido" (p. 219); hay por esos sitios una visión de cadáveres con el "olor de sus mutilaciones" (p. 220). De las ruinas del centro de Bogotá durante el Bogotazo, se distinguen en El incendio de abril (Torres, 2012), las "sombras que se mueven o se desvanecen entre el humo y la lluvia, como fantasmas" (p. 201). Y de las casuchas destrozadas de San José en las escenas que presenta Los ejércitos (Rosero, 2007), brota "de vez en cuando un lamento lejano (...) un llamado, un nombre a gritos, un nombre cualquiera, pasos a la carrera, ruidos indistintos que declinan y son reemplazados por el silencio absoluto" (p. 105).

Ciertamente, todo derrumbe de los referentes espa- ciales impiden la memoria, ya que hay implícito a todo proceso de desterritorialización un proceso de des-subjetivación, en el que la identidad del sujeto y el reconocimiento de la tradición queda en entre dicho por la necesidad de adaptarse a unas normas siempre cambiantes y por el impacto mismo que produce cada nueva arremetida. Un suceso traumático desplaza al otro rápidamente, sin dejar espacio para tomar distancia y descifrar su contenido; circunstancia que dificulta la construcción de un relato apropiado sobre lo pasado. Explica Pécaut (2004, p. 3-5) que en estas situaciones, la única narrativa que existe es la individual cuando cada quien reconstruye su línea de vida. Mas la mayor parte de las veces se hace describiendo la trayectoria espacial, los pueblos o sitios sucesivos de residencia, que por lo general han sido arrasados por la guerra. Se trata entonces, de una memoria espacial que se ancla en lugares siempre perdidos, "ubicada en el vacío", sin lugar concreto donde posicionarse.

Ahora bien, el hecho de que los escritores tiendan a escoger lugares simbólicos o lugares de la memoria ${ }^{7}$ de la historia colombiana para situar estratégicamente en ellos a sus personajes, dice no sólo de la estrecha relación del héroe vagabundo con los espacios en que deambula, sino y sobre todo de una mirada transgresora que busca relativizar el discurso gubernativo, pues la narración levanta de los escombros otras razones de lo que pasó. Esto, porque si los sitios simbólicos tienen la "función mnemotécnica" (Aínsa, 2006, p. 48) de no dejar en el olvido el significado que cada discurso oficial ha dado a pueblos, plazas, avenidas, monumentos, etc., al ser registrados en la ficción como ruinas, se hacen metáfora de la calamidad política y la identidad derruida; deconstruyen no sin cierto matiz mordaz, la trascendencia ceremonial de tales sitios.

El espacio urbanizado y su irradiación simbólica condiciona la memoria individual, pero pesa también sobre el sujeto como auténtico arquetipo de memoria colectiva (Aínsa, 2006, p. 135). De ahí que la urbe y sus lugares legendarios

6 El Aro, un caserío ubicado al norte de Antioquia, Colombia, fue arrasado el 22 de octubre de 1997 por tropas paramilitares. 150 hombres de las Autodefensas Campesinas de Córdoba y Urabá (Accu), conocidos en la región como los "Mochacabezas", llegaron al corregimiento y asesinaron a 17 personas. Los paramilitares permanecieron 7 días en el lugar durante los cuales torturaron públicamente a las víctimas. Luego de la masacre quemaron 42 de las 60 casas de la vereda, se robaron 1.200 reses y ocasionaron el desplazamiento forzado de 702 habitantes de la región. La fuerza pública dejó desprotegida a la población. La Corte Interamericana de Derechos Humanos (CIDH) condenó al Estado colombiano a pagar una indemnización cercana a 3.400 millones de pesos a favor de 123 familiares de las víctimas. (Centro Nacional de Memoria Histórica)

7 Sintagma utilizado por Pierre Nora (1997) para significar los lugares en los que se ha anclado la memoria colectiva y la vasta topología de la simbólica cultural de las ciudades. 
se identifiquen claramente en cada una de las ficciones escogidas para este estudio: Ana Barbusse, narradora de El incendio de abril (Torres, 2012), transita meramente la zona afectada por el 9 abril de 1948; ella hace énfasis en los nombres y descripciones de las calles, plazas, monumentos, avenidas y edificaciones que recorre mientras busca a su esposo. Inclusive la novela a modo de paratexto, tiene en la primera página el mapa del centro de Bogotá, una abstracción del panorama real, señalando los lugares donde se desató la refriega una vez conocida la muerte de Gaitán. En Los ejércitos y Los derrotados se dan los nombres concretos y las nomenclaturas precisas de cada sitio: Bojayá, El Aro, San José ${ }^{8}$, Antioquia, Turbo, etc., donde Ismael Pasos y Andrés Ramírez tienen sus experiencias. Cada novelista configura una especie de triada dialógica entre espacio, tiempo y memoria para significar la identidad individual y social, develar los acontecimientos de triste memoria y recuperar para el presente un "saber obligatorio" sobre el surgimiento del país.

Las urbes resguardan explicaciones del pasado que permiten comprender el presente y dotar de razones el futuro; ellas son los "tiempos acumulados" (Aínsa, 2006, p. 52) que configuran un lenguaje recogido a lo largo de la historia y constituyen lo comunitario. De ahí que las narraciones hagan énfasis desde el desplazamiento infatigable del héroe, en traducir en palabra o imagen los despojos de los sitios andados, en rescatarlos para nuestra mirada y hacerlos hablar para la memoria adormecida (Giannini, 2010, p. 17). A continuación se cita parte de los recorridos de Ana Barbusse por el centro de la capital, arrasado por la indignación violenta del pueblo frente al asesinato de su líder político:

Al llegar a la séptima veo arder el hermoso edificio de la Gobernación, vecino a la iglesia de San Francisco. Frente a ese incendio hay dos tranvías quemados y las ruinas de otro en la Séptima, frente al lugar donde fue asesinado Gaitán (...) Del otro lado se ven las manzanas que arden del Parque Santander hacia el norte. En la esquina de ese parque el hotel Regina es una llamarada que se abalanza como una mano gigantesca carbonizando los tejados vecinos (...) Un puñado de hombres empieza a disparar contra el ejército desde el centro de la plaza. Dos de ellos se encaraman al pedestal de la estatua de Nariño y disparan sirviéndose del prócer como escudo (...) La plaza es un espanto.
San Victorino, un laberinto infernal. (Torres, 2012, p. 204-14)

La novela de Torres permite un horizonte de sentido mucho más profundo sobre el momento crucial que los especialistas señalan como el pico y el inicio de la Violencia bipartidista (Gómez, 2008 p. 15-63; Guzmán Campos et al., 2010, p. 48-157; Melo, 1992, p. 50-123; Oquist, 1972, p. 155-233; Palacios y Safford, 2002, p. 629-70; Pécaut, 2001, p. 21-85), porque aunque el suceso ha sido ampliamente documentado con hechos concretos: cifras de muertes, regiones implicadas, análisis políticos, cocientes económicos, etc., el rastro íntimo de esa guerra, la secuela emocional que perdura en la subjetividad social, sigue ignorándose; mas es precisamente ahí, en la negación de los estragos íntimos de la violencia, donde la ficción cumple una función importante: desde las problemáticas y la emocionalidad de los personajes sostiene otro discurso, desentraña las pérdidas más comprometedoras y esclarece una verdad sobre la historia del país más cercana a la sensibilidad e inteligencia del ciudadano común.

Desde esa perspectiva Montoya (2012) en las andanzas

8 Rosero afirma que su novela "está ubicada en un pueblo imaginario de Colombia, cualquier pueblo, cualquier aldea, sometida al conflicto desafortunado" (Junieles, 2007, p. 1). Desde ese punto de vista, deducimos que "San José" aunque "pueblo imaginario", es producto de la mezcla de la realidad con la fantasía, la formulación literaria de la fusión de varios espacios reales acometidos por la violencia. 
de su héroe, Andrés Ramírez, traza, con "osada fidelidad" a lo acontecido, las fechas, los personajes históricos y la ubicación geográfica de los pueblos que la narco-guerra ha descuajado. En la figuración de los sucesos reales logra deducirse un afán del escritor por hacer claridad que aunque enfrentados a una ficción, lo narrado sucedió, sucede todavía, los sitios existen, las víctimas exigen un reconocimiento y el doloroso recuerdo debe conservarse. Hay un énfasis marcado a lo largo de la narración en lo difícil que resulta liberar nuestros recuerdos y olvidos del contexto que los determina, ya que precisamente es la memoria plural, por triste que sea, la razón de ser de todo pueblo e individuo. Veamos:

\section{Bojayá, Chocó, mayo de 2002}

Ahora le ha tocado el turno a la cabecera de Bellavista, en el municipio de Bojayá, en el departamento del Chocó, en el occidente de la República de Colombia... A finales de abril de 2002, bajan por el río Atrato tropas paramilitares del frente Élmer Cárdenas (...) ¡Ah, las iglesias en el mundo! Quebradizas en el fondo (...) La de San Pablo Apóstol es chica. La han construido los mismos habitantes (...) Y ahora está recibiendo las familias que llegan con sus pocos atavíos (...) Entran cien. Ciento cincuenta. Doscientas. Entran trescientas personas (...) El miedo se apretuja todavía más en el recinto (...) Y están diciendo Líbranos del mal cuando la primera explosión sacude los cimientos de la Iglesia. (Montoya, 2012, p. 232-34)

Esta escena se percibe como una prolongación fiel de la realidad", donde "pareciera" no haber intención estética de distinguir lo histórico de lo ficcional, pues en ambos espacios reina una indiscernibilidad de lo real ${ }^{10} \mathrm{y}$ de lo imaginario que no busca ser escamoteada. Es una caracterización narrativa que sugiere la idea de un texto anfibio, es decir, que transita en una especie de movimiento pendular, entre la realidad y la ficción (Garramuño, 2009, p. 54). Toda la trama es atravesada por pasajes ficcionales, netamente literarios, significativamente permeados por lo histórico, donde de alguna manera la novela se vuelve "registro verídico" de un devenir roto, la formulación literaria de una historia esquiva que tiende a perderse en la desmemoria de la sociedad actual.

Respecto a la relación entre literatura y mundo, Deleuze y Guattari (2002) proponen el concepto de "libro rizoma", donde no hay imitación ni semejanza, sino surgimiento a partir de dos naturalezas heterogéneas: la realidad y la ficción. De esta forma y siguiendo a los filósofos franceses, la literatura no sería una representación llana del mundo si su proceso logra un lenguaje nuevo, que esclarezca una entidad diferente de la realidad. Un lenguaje nuevo como resultado de una "comunicación aparalela” (Deleuze y Guattari, 2002, p. 14), donde cada uno: libro y mundo, se sirve del otro para rebrotar sentidos ignorados.

Así entonces, puede afirmarse, por todo lo anterior, que la configuración ficcional va más allá, y en el caso de nuestro corpus literario, es resultado original de una fusión de los sucesos colombianos y de la imaginación de cada autor. Las tres novelas aseguran

9 La masacre de Bojayá se inscribe en el continuo y cruento enfrentamiento que entre el 20 de abril y el 7 de mayo de 2002 sostuvieron la guerrilla de las FARC y un comando paramilitar en las inmediaciones de las cabeceras municipales de Bojayá -conocida en la región como Bellavista- y Vigía del Fuerte, municipio vecino perteneciente al departamento de Antioquia, Colombia. Bellavista se vio enlutada tras la explosión de una pipeta de gas llena de metralla que las FARC lanzaron contra los paramilitares, quienes se ocultaban tras el recinto de la iglesia donde se refugiaban más de 300 personas. (Grupo de Memoria Histórica, 2010)

10 Según Deleuze (2007), la indiscernibilidad de lo real y de lo imaginario, o de lo presente y de lo pasado, de lo actual y de lo virtual, no se produce solamente en la cabeza o en el espíritu, sino que es el carácter objetivo de algunas imágenes existentes, dobles por naturaleza. 
la desterritorialización de las múltiples comprensiones de la violencia, y a su vez la violencia y sus efectos reterritorializa la producción literaria, que a su vez se desterritorializa en sí misma en la realidad que configura. Momento último que se traduce como la esencia de lo literario, y permite explicar, en cierta medida, la complejidad de la ficción como registro de lo histórico o biográfico.

\section{El héroe derrotado: un vagabundo de la memoria}

La perspectiva narrativa del personaje nómada es la que da forma a cada novela escogida para este texto. La progresión de la intriga surge de la indagación de un sujeto vapuleado por las terribles caminatas; la angustia por lo desconocido; la esperanza minada frente a la búsqueda infructuosa de alguien; el cansancio espiritual y la conciencia de la derrota. Su envestidura es concomitante al eclipse de determinadas utopías políticas, donde la ilusión del triunfo poco importa, por lo menos en lo que atañe al ideal sociopolítico de las generaciones pasadas y su deseo imperioso de fundar un nuevo estado de lo social. Maíz (2013, p. 8) explica que parte de la narrativa contemporánea, está orientada a la incorporación de la figura del derrotado, del per- dedor, del que no aspira desafiar su destino y si lo hace no lo hará con aquellos recursos que probaron ser conducentes al fracaso.

Ahora bien, es necesario aclarar que se habla de un héroe perdedor, mas no de un béroe fracasado, porque aunque el perdedor presiente la frustración de sus proyectos y reconoce la imposibilidad de la lucha, insiste en ello, se hace metáfora de un principio de emancipación, y de cierta manera, defiende su condición de derrotado, alcanzando en ese estatus, paradójicamente, otra dimensión de éxito: la de "pertenecer a un grupo superior de triunfadores: el de los que han resistido y fundan su victoria en la orgullosa aceptación de la derrota" (Amar, 2010, p. 68). El fracasado, en cambio, carece de hondura política, poco resiste a la desmemoria, se enfrasca en la melancolía y se conforma con lo establecido.

Andrés Ramírez, personaje de Los derrotados, signado ya desde el título mismo del libro por la desesperanza y la pérdida, se presenta como un "perdedor ético" (Amar 2010, p. 40), crítico frente a una realidad sociopolítica criminal que ha obstaculizado desde el nacimiento del país los proyectos de cada nueva generación, pero consciente también de su impotencia para cambiarla. Como heredero de la gente derrotada, de aquella que nunca llevó a feliz término los ideales de vida, busca la forma de seguir resistiendo, es por eso que la fotografía se convierte en su punto de fuga, con cada imagen recupera lo reprimido y refiere la historia a los otros.

Desde el motivo del viaje, extensión de la condición nomádica, recorriendo los lugares de la masacre, Ramírez registra la creciente pérdida del territorio, tanto como espacio físico como en lo simbólico-cultural. Su enfoque de la violencia permite la articulación de uno de los discursos contemporáneos más polémicos sobre el periodismo incorporado y la ética de la fotografía de guerra (Sontang, 2004, p. 1-7; Cavarero, 2009, p. 95-102; Butler, 2010, p. 95-144). Constantemente Montoya (2012) pone a su personaje a reflexionar sobre cuál sería la forma y la distancia más eficaz para revelar el sufrimiento; persiste el interrogante sobre cómo sacar del "limbo de los negativos" las caras atravesadas por el dolor; de qué manera tratar la imagen de la muerte escabrosa, de mostrarla a la gente sin que se acostumbren a ver esos hombres y mujeres sin nombre, y piensen que las fotografías son extraordinarias y familiares (Montoya, 2012, p. 108).

Se articula en la novela, desde los intereses profesio- 
nales de Ramírez, el discurso de toda una tradición de fotógrafos de guerra: Robert Capa, Mathew Brady, Alexander Gardner, James Nachtwey, con el propósito de reflexionar y debatir sobre cuál sería, a la sazón, el enfoque más acertado para significar la calamidad y el horror. Son deducciones que canalizan en la trama literaria el discurso ético de la imagen, las diversas formas como se enmarca la muerte del inerme y la capacidad de respuesta del espectador.

Ramírez sólo permaneció en la iglesia de Bojayá media hora. El olor era insoportable, lo dejaron entrar con varios hombres. Estos sacaron los cuerpos mutilados y los metieron en bolsas (...) recorrió los vestigios del templo. En algún momento hizo una pausa para mirar dónde pisaba. Vio un perro carbonizado. Vio un manojo de miembros humanos que no logró identificar. Vio el Cristo crucificado (...) Se distanció, enfocó su cámara y disparó. La cabeza, el tórax sin brazos y un pedazo de pierna del Cristo están en primer plano. Bancas, ropas, tablas, libros, cocas, platos destrozados en medio de la tierra y el agua. Al fondo está la puerta y las ventanas derruidas. La luz de afuera entra por ellas con sed descomunal. (Montoya, 2012, p. 220-36)
Hay en este pasaje una sensación del horror, un estado de ánimo donde el yo se perturba, pues difícil es mirar sin estremecerse. Es un marco de guerra ${ }^{11}$ donde se condensa la memoria de los olvidados y se enfrenta la condición infame del país oficial. Desde las fotografías de Ramírez, la narración fija un acto de ver desobediente, pues cada imagen contiene un fuerte trasfondo político que impugna al Estado y muestra lo que éste no quiere que se muestre.

Explica Butler (2010, p. 101), que la fotografía actúa sobre nosotros, inclusive en contra de la voluntad propia; apela siempre a nuestro sentido de obligación moral al ser un dispositivo estructurador de significación, una imagen que perturba tanto al que hace la foto como al que la mira. Se define en ella la forma como la observamos al relacionar estrechamente el contexto que nos atañe. Por ello, los lugares que se revelan en las fotografías de Ramírez, no sólo concretan un presente ficcional, incorporan también todas las guerras pasadas de la historia colombiana; las de hoy y las posibles, pues seguimos en un país hundido en el espanto y el crimen. Son fijaciones de la verdad que como motivo ético ejercen el poder de inquietar a quien las mira y sacarlo del letargo de la resignación o la indiferencia. Cada imagen en la novela fija en la memoria el espinoso territorio que se habita y penetra críticamente en la subjetividad tanto del que escribe, como del que narra, de lo narrado y del narratario.

\section{De voces y silencios o la exploración emocional pura}

Aunque los escritores escogidos abren la posibilidad de una lectura crítica de la violencia sociopolítica desde la práctica visceral del nomadismo, en el sentido que los personajes van deambulando con sus cuerpos el territorio destrozado, dejándose atravesar por éste para presentarlo desde las entrañas, el tono adoptado para contar tales avatares se aleja de lo melancólico o lastimero; el narrador no dispone del tiempo necesario para interiorizar las vejaciones a las que es sometido, por consiguiente, va refiriendo las experiencias de manera llana, con descripciones escuetas, limitadas a las primeras impresiones de cada situación. No hay afán de explicación de las circunstancias cuando se está frente a los pasajes más crudos de la violencia. La narración

11 Expresión utilizada por Judith Butler (2010) para señalar el sentido problemático del ámbito de representabilidad de la guerra que se enmarca en una fotografía: no puede comprenderse simplemente su contenido explícito, puesto que está constituido fundamentalmente por lo que se deja fuera, por lo que se mantiene fuera del marco dentro del cual aparecen las representaciones (p. 108). 
es más bien una "presentación precisa" de la escena macabra; es la exploración emocional pura, instantánea, fragmentada, de los efectos que la guerra produce sobre las subjetividades presentes en cada pasaje.

Por ejemplo, el relato de Ana Barbusse en El incendio de abril, toma forma entre las notas y cartas que va dejando a su esposo, desaparecido durante el Bogotazo, y un eterno monologar a medida que circula las calles devastadas del centro de la capital. Este personaje es tal vez una de las presencias más ambiciosas de la novela; su narración permite al lector una comprensión de los sucesos acontecidos ese 9 de abril de 1948. Ella menciona lo que va encontrando a su paso; se escabulle por los callejones, sortea incendios, establece rápidos y extraños contactos con otros. Su andar atormentado es una cartografía simbólica de los lugares emblemáticos de la capital; devastados ahora por los saqueos, la metralla, los tanques y los incendios. Esta heroína permite un registro semántico de la pérdida y la barbarie cuando se traspasa el límite de la indignación y la intolerancia:

Salgo al aguacero y sigo subiendo arrimada a los muros, se ve poca gente, casi nadie, quizás por eso es que en esta calle no se oyen disparos, alrededor sí, pero alrededor viene siendo muy cerca, San Victorino, la Jiménez, la plaza de Bolívar (...) las puertas y ventanas de estos locales han sido arrancadas de sus goznes (...) veo grandes llamaradas alzarse dos manzanas arriba, y al cruzar la bocacalle de un estrecho callejón, oigo gritos y gemidos atravesados por el llanto inconfundible de un niño. Vuelvo la mirada. La imagen que veo entre los velos de la lluvia, alumbrada por la luz mortecina de un poste, hace que me detenga (...) un hombre se escuda detrás de otro al que un soldado le clava la bayoneta en el vientre. Una mujer arrodillada frente a otro soldado que le apunta con su fusil, se tapa los ojos con la mano mientras abraza contra su cuerpo a un niño. A los pies de un tercer soldado resplandece la blancura ensangrentada de un perro ensartado en su bayoneta. Estoy horrorizada. (Torres, 2012, p. 219).

Ahora bien, puede apreciarse en la cita anterior que la narradora presenta escuetamente la guerra, su voz es un rastreo directo del horror y la insensatez. El autor no la retiene para analizar o profundizar en las consecuencias de la devastación, ni para ofrecer un punto de vista personal o filtrar un discurso explícito sobre la realidad violenta. El tratamiento de la guerra se registra como una imagen fugaz, afín al "callejeo" (Benjamin, 2005, p. 435) escabroso de quien la narra, donde la fijación de una idea explicativa sobre lo que se ve, se hace innecesaria para significar la profundidad del fenómeno. Es una forma de contar, que puede entenderse como extensión del estado nomádico, donde la fijación de sentido es la suma de las experiencias momentáneas, terribles, que la heroína va teniendo a cada paso. Desde la perspectiva de Oubiña (2011, p. 48) puede aseverarse que tal estilo narrativo, presente en las tres novelas elegidas, apunta desde el personaje nómada hacia un exterior donde el lenguaje aclaratorio se hace redundante para nombrar lo extremo, acogiéndose entonces a la descripción precisa, entrecortada, a un intento de narración sin destino, que se limita a bordear con recelo cada impresión traumática que se percibe.

En ese orden de ideas, las presencias nómadas en las novelas de Torres y Rosero: Ismael y Ana, sufren directamente sobre su cuerpo y su psiquis los estragos de la guerra; la narración avanza en el momento mismo en que estos personajes deambulan por los escombros, su andar es la fuerza propulsora del relato. Es una especie de recurso retórico que circunscribe la existencia del héroe exclusivamente a un presente instantáneo, donde se limita a contar lo que ve y lo que siente en el momento mismo en que narra, un relato de impresiones pasajeras, donde pocas veces se recurre a una experiencia pasada 
y mucho menos se habla sobre un futuro. Un juego formal que sugiere la idea de un sujeto sin historia ni porvenir, donde el flujo de un tiempo con dirección ha dejado de estructurar la existencia, pues para estos errantes el tiempo, en el terreno, no tiene ya ni un "hacia adelante" ni un "hacia atrás"; lo único que cuenta es la habilidad de moverse y no quedarse quietos (Bauman, 2001, p. 115). En cada paso dado aunque obtienen un rasgo que les da espesor y vitalidad, también se desprende cierta sensación de lo frágil y lo precario. Son ellos el reflejo duro y cortante de lo innombrable y fugitivo:

Vi que la estufa rodante se cubría velozmente de una costra de arena rojiza, una miríada de hormigas que zigzagueaban aquí y allá, y, en la paila, como si antes de verla ya la presintiera, medio hundida en el aceite frío y negro, como petrificada, la cabeza de Oye: en mitad de la frente una cucaracha apareció, brillante, como apareció, otra vez, el grito: la locura tiene que ser eso, pensaba, huyendo, saber que en realidad el grito no se escucha, pero se escucha por dentro, real, real; huí del grito, físico, patente, y lo seguí escuchando tendido al fin en mi casa, en mi cama, bocarriba, la almohada en mi cara, cubriendo mi nariz y mis oídos como si pretendiera asfixiarme para no oír más. (Rosero, 2007, p. 200)

La voz de Ismael Pasos es el hilo de contención de este pasaje. La imagen de la decapitación empuja al héroe a un deambular afiebrado; en los límites de la locura su monologar alude una "realidad incomunicable", sondea un vacío oscuro, donde el lenguaje o el gesto nunca alcanza a significar del todo lo que corroe el alma; sin embargo, convoca y asedia el sentido profundo de lo que resulta indecible: la experiencia del límite, donde el horror extremo hace presencia en los cuerpos mutilados y el aniquilamiento absoluto del sujeto.

En definitiva, la propuesta narrativa del conjunto de obras referidas están atravesadas por un principio nómada, donde el trasegar obstinado del héroe condensa diversas miradas de la historia de un país arrasado por la violencia sociopolítica. Se da cuenta de una literatura configurada desde un sentimiento de la pérdida, donde ya no hay lugar para el imaginario utópico o mítico, y se ha perdido la convicción generalizada de otras épocas, por ejemplo la de los años setenta en Latinoamérica, en cuanto a que el presente era el lugar en el que había que estar. Empero, aunque cada ficción es alegoría del desencanto político al mostrar que aquellos objetivos que parecieron triunfantes, carecen ahora de valor, $y$ no han sido otra cosa que una máscara para ocultar la corrupción, el privilegio y el abandono de los ideales (Maíz, 2013, p. 9), es también la "metáfora de la historia" y un recurso para la desmemoria, donde el héroe derrotado, nómada, se resignifica a sí mismo, y en su progresión sin horizonte plantea otras facetas de la realidad nacional.

\section{Referencias}

Aínsa, F. (2006). Del topos al logos: propuestas de geopoética. Madrid: Gedisa.

Aínsa, F. (2012). Palabras nómadas. Nueva cartografía de la pertenencia. Madrid: Vervuert.

Amar Sánchez, A. M. (2010). Instrucciones para la derrota. Narrativas éticas y políticas de perdedores. Barcelona: Anthropos.

Avilés, F. J. (2012). "Estética del derrumbe: Escritura y deambular urbano en la obra de Eduardo Lalo". Revista Iberoamericana, LXXVIII (241), 873-92. 
Bauman, Z. (2001). La posmodernidad y sus descontentos. (M. Malo, y C. Piña, trad.) Madrid: Akal.(Trabajo original publicado en 1997).

Benjamin, W. (2005). Libro de los pasajes. Apuntes y materiales. (J. Aguirre, trad.) Madrid: Taurus.

Butler, J. (2010). Marcos de guerra. Las vidas lloradas. (B. Moreno, trad.) Madrid: Paidós. (Trabajo original publicado en 2009).

Cassigoli, R. (2011). Morada y memoria. Antropología poética del habitar humano. Barcelona: Gedisa.

Cavarero, A. (2009). Horrorismo. Nombrando la violencia contemporánea. (S. Agra, trad.). Barcelona: Anthropos. (Trabajo original publicado en 2007).

Centro Nacional de memoria histórica. Rutas del conflicto. Masacre de El Aro. Recuperado el 3 de junio de 2014, de http:// rutasdelconflicto.com/interna.php?masacre $=25$.

Deleuze G. (2007). La imagen-tiempo: estudios sobre cine 2 (I. Agoff, trad.) Barcelona: Paidós. (Trabajo original publicado en 1985).

Deleuze G. y Guattari F. (2002). Mil mesetas. Capitalismo y esquizofrenia. (J. Vásquez, con la colaboración de U. Larraceleta, trad.) Valencia: Pretextos. (Trabajo original publicado en 1980).

Escobar, A. (2000). Literatura y violencia en la línea de fuego. En: M.M. Jaramillo, B. Osorio y A.I. Robledo. Literatura y cultura narrativa colombiana del siglo XX (pp. 321-38). Bogotá: Ministerio de cultura.

Garramuño, F. (2009). La experiencia opaca. Literatura y desencanto. Buenos Aires: Fondo de cultura económica.

Giannini, H. (1987). La reflexión cotidiana. Santiago de Chile: Universitaria.

Giannini, H. (2011). Prólogo. En R. Cassigoli. Morada y memoria. Antropología y poética del habitar bumano (pp. 7-12). Barcelona: Gedisa.

Grupo de memoria histórica. (2010). Bojayá, la guerra sin límites. Informe del grupo de memoria histórica de la comisión nacional de reparación y reconciliación. Bogotá: Aguilar, Altea, Taurus, Alfaguara, S.A.

Guzmán Campos, G., Fals Borda, O. y Umaña Luna, E. (2010). La violencia en Colombia (Vols. 1, 2). Bogotá: Debolsillo.

Junieles, J. J. (2007). Evelio Rosero Diago. Desde la paz preguntan por nosotros. Revista Letralia, (164), 21. Recuperado el 18 de marzo de 2011, de http://www.letralia.com/164/entrevistas01.htm.

Maíz, C. (2013). A falta de épica buenas son las historias. El 'héroe' en la narrativa latinoamericana actual. Revista Iberoamericana de Literatura. (En prensa).

Maffesoli, M. (2005). El nomadismo. Vagabundeos iniciáticos. (D. Gutiérrez, trad.) México: Fondo de cultura económica. (Primera impresión en francés, 1997)

Melo, J. O. (1992). Predecir el pasado: ensayos de historia de Colombia. Bogotá: Fundación Simón y Lola Guberek. 
Montoya, P. (2012). Los derrotados. Medellín: Sílaba.

Montoya, P. (2013). Retratos de un país invisible: fotografías de Jorge Mario

Múnera. Recuperado el 15 de abril de 2013 de http://www.pablomontoya.net/retratos-de-un-pais-invisiblefotografias-de-jorge-mario-munera/.

Oubiña, D. (2011). El silencio y sus bordes: modos de lo extremo en la literatura y el cine. Buenos Aires: Fondo de cultura económica.

Oquist, P. (1978). Violencia, conflicto y politica en Colombia. Bogotá: Banco Popular.

Palacios, M. y Frank S. (2002). Colombia. País fragmentado, sociedad dividida. Su historia. (A. García, trad.) Bogotá: Norma. (Impresión en inglés, 2002)

Pécaut, D. (2001). Guerra contra la sociedad. Bogotá: Espasa.

Pécaut, D. (2004). Memoria imposible, historia imposible, olvido imposible. En: Memorias en conflicto. Aspectos de la violencia política contemporánea. Perú: Institut français d'études andines.

Rosero, E. (2007). Los ejércitos. Barcelona: Tusquets.

Sánchez, G. (2008). Guerra y politica en la sociedad colombiana. Bogotá: Debolsillo.

Sontang, S. (Jun./Jul. 2004). “Ante la tortura de los demás”. Revista El Malpensante, (55), 20-28. Recuperado el 22 de agosto de 2013 en http:/ / elmalpensante.com/index.php?doc=display_contenido\&id=1114

Sontang, S. (2011). Ante el dolor de los demás. (A. Major, trad.). Bogotá: Debolsillo.

Torres, M. (2012). El incendio de abril. Bogotá: Alfaguara.

Torres, M. (2013). Los escritores buscamos lo que no existe. Buenos Aires: La voz.

Recuperado el 3 de enero de 2014 de: http://www.lavoz.com.ar/ciudad-equis/miguel-torres-los-escritoresbuscamos-lo-que-no-existe 